\title{
KEBUTUHAN PERAWATAN ORTODONTI BERDASARKAN INDEX OF ORTHODONTIC TREATMENT NEED PADA USIA REMAJA 15 - 17 TAHUN
}

\author{
${ }^{1}$ Axel B. Oley \\ ${ }^{2}$ P. S. Anindita \\ ${ }^{2}$ Michael A. Leman
${ }^{1}$ Kandidat Skripsi Program Studi Pendidikan Dokter Gigi Fakultas Kedokteran Email: axelbeiby@yahoo.co.id \\ ${ }^{2}$ Program Studi Pendidikan Dokter Gigi Fakultas Kedokteran Universitas Sam Ratulangi
}

\begin{abstract}
Dental and oral health is an important factor that must be maintained. Some conditions such as malocclusion can affect dental and oral health. Orthodontic treatment aims to correct the malocclusion as well as the appearance of a person's face. This was a descriptive study. This study aimed to determine the needs of orthodontic treatment based on Index of Orthodontic Treatment Need (IOTN). This IOTN consists of two components, namely the Aesthetic Component (AC) and the Dental Health Component (DHC). This study was conducted in SMAN 3 Tondano. There were 390 students. Data collection were performed by inspection and measurement using the AC and DHC. The results showed that based on the AC 85.94\% did not need or need only little treatment, 9.37\% needed borderline treatment, and $4.69 \%$ really needed treatment. Meanwhile, based on DHC 51.56\% did not need or need only little treatment, 35.94\% needed borderline treatment, and $12.5 \%$ really needed treatment.
\end{abstract}

Keywords: malocclusion, index of orthodontic treatment need, aesthetic component, dental health component.

\begin{abstract}
Abstrak: Kesehatan gigi dan rongga mulut merupakan faktor penting yang harus dijaga. Hal yang mempengaruhi masalah kesehatan gigi dan rongga mulut salah satunya ialah maloklusi. Penerapan kebutuhan perawatan ortodonti ditujukan untuk memperbaiki maloklusi yang dapat mempengaruhi kesehatan gigi dan rongga mulut serta penampilan wajah seseorang. Penelitian yang dilakukan merupakan suatu penelitian yang bersifat deskriptif. Tujuan dari penelitian ini untuk mengetahui kebutuhan perawatan ortodonti berdasarkan Index of Orthodontic Treatment Need (IOTN), yang terdiri dari dua komponen yaitu Aesthetic Component (AC) dan Dental Health Component (DHC). Penelitian dilakukan di SMA negeri 3 Tondano dengan jumlah siswa 390 orang. Pengambilan data dilakukan dengan pemeriksaan dan pengukuran menggunakan AC dan DHC. Hasil penelitian menunjukan bahwa berdasarkan AC 85,94\% tidak/sedikit membutuhkan perawatan, 9,37\% membutuhkan perawatan borderline dan 4,69\% sangat membutuhkan perawatan, sedangkan berdasarkan DHC 51,56\% tidak/sedikit membutuhkan perawatan, 35,94\% membutuhkan perawatan borderline dan 12,5\% sangat membutuhkan perawatan.
\end{abstract}

Kata kunci: maloklusi, index of orthodontic treatment need, aesthetic component, dental health component.

Angka kejadian maloklusi di Indonesia cukup tinggi. Prevalensi maloklusi pada tahun 2008 di Indonesia mencapai $80 \%$ dan menduduki peringkat ketiga setelah karies gigi dan penyakit periodontal. ${ }^{1}$ Keadaan maloklusi akan berdampak pada estetika wajah, masalah pada fungsi oral, dan penyebab terjadinya penyakit periodontal. Terdapat berbagai alasan orang 
dewasa menginginkan perawatan ortodonti. Hasil penelitan yang telah dilakukan menyatakan bahwa sebagian besar responden pasien ortodonti dewasa yang diteliti memilih penampilan sebagai motivasi utama bagi perawatan ortodonti. Kehilangan gigi, kebutuhan restorasi dan kerusakan jaringan periodontal menjadi alasan lain pasien dewasa menggunakan perawatan ortodonti. ${ }^{2}$

Maloklusi dan kelainan rongga mulut merupakan masalah yang perlu diperhatikan, maka dianggap perlu suatu standar penilaian terhadap kebutuhan perawatan ortodonti seperti Index of Orthodontic Treatment Need (IOTN). Penilaian kebutuhan perawatan ortodonti berdasarkan IOTN telah disepakati secara internasional karena metode ini terbukti valid, dapat dipercaya, dan mudah digunakan. Index of orthodontic treatment need (IOTN) memiliki dua bagian yaitu Aesthetic Component (AC) merupakan penilaian dalam bentuk fotografi dan Dental Health Component (DHC) untuk menilai beberapa jenis maloklusi. ${ }^{3}$

Peneliti menganggap penting untuk melakukan penelitian ini karena saat ini belum tersedia data statistik di desa Kembuan mengenai kebutuhan perawatan ortodonti. Alasan lainnya adalah Sekolah Menengah Atas Negeri 3 Tondano merupakan usia remaja yang berkisar 15-17 tahun. Masa remaja merupakan tahap penting yang terjadi pada tiap orang, terjadi banyak perkembangan dalam tahap ini yaitu perkembangan fisik, kepribadian dan perkembangan emosi, serta rentan terhadap masalah maloklusi. Peneliti tertarik untuk meneliti seberapa besar kebutuhan perawatan ortodonti siswa-siswi SMA Negeri 3 Tondano di Desa Kembuan.

\section{BAHAN DAN METODE PENELITIAN}

Penelitian ini merupakan suatu penelitian yang bersifat deskriptif, dengan menggunakan metode cross sectional study dan dilaksanakan di desa Kembuan. Penelitian dilakukan di SMA Negri 3 Tondano pada bulan November 2014. Populasi dalam penelitian ini ialah siswa-siswi SMA Negri 3 Tondano yang berjumlah 390 siswa. Metode pengabilan sampel pada penelitian ini menggunakan metode cross sectional study.

Data primer diambil dari hasil pengukuran
AC dan DHC berdasarkan IOTN. Data sekunder mencakup jumlah siswa, kelompok usia dan jenis kelamin.

Data di sajikan dalam bentuk tabel berdasarkan usia, jenis kelamin, AC dan DHC kemudian di analisis berdasarkan presentase.

\section{HASIL PENELITIAN}

Subjek penelitian berjumlah 64 siswa dan berdasarkan karakteristiknya dapat dibedakan berdasarkan jenis kelamin dan usia (Tabel 1 dan 2).

Tabel 1. Karakteristik subjek berdasarkan jenis kelamin

\begin{tabular}{ccc}
\hline $\begin{array}{c}\text { Jenis } \\
\text { kelamin }\end{array}$ & Jumlah & (\%) \\
\hline Laki-laki & 27 & 42,18 \\
Perempuan & 37 & 57,82 \\
Total & 64 & 100 \\
\hline
\end{tabular}

Tabel 2. Karakteristik subjek berdasarkan usia

\begin{tabular}{ccc}
\hline Usia & Jumlah & $(\%)$ \\
\hline 15 tahun & 20 & 31,25 \\
16 tahun & 23 & 35,94 \\
17 tahun & 21 & 32,81 \\
Total & 64 & 100 \\
\hline
\end{tabular}

Hasil penelitian dapat didistribusikan berdasarkan AC dan dapat dikelompokan menurut kriteria tidak/ sedikit butuh perawatan, butuh perawatan borderline, dan sangat butuh perawatan (Tabel 3).

Hasil peneltian dapat didistribusikan berdasarkan DHC juga dapat dikelompokan menurut kriteria tidak /sedikit butuh perawatan, butuh perawatan borderline, dan sangat butuh perawatan (Tabel 4).

Hasil pemeriksaan AC dapat didistribusikan berdasarkan jenis kelamin laki- laki dan perempuan (Tabel 5).

Hasil pemeriksaan DHC dapat didistribusikan berdasarkan jenis kelamin laki- laki dan perempuan (Tabel 6).

Hasil penelitian dapat dibandingkan berdasarkan AC dan DHC (Tabel 7). 
Jurnal e-GiGi (eG), Volume 3, Nomor 2, Juli-Desember 2015

Tabel 3. Distribusi Aesthetic Component

\begin{tabular}{|c|c|c|c|}
\hline Aesthetic Component (AC) & Nilai & $\mathrm{n}$ & $(\%)$ \\
\hline & 1 & 23 & 35,94 \\
\hline \multirow{3}{*}{$\begin{array}{l}\text { Tidak/butuh } \\
\text { ringan }\end{array}$} & 2 & 14 & 21,87 \\
\hline & 3 & 5 & 7,81 \\
\hline & 4 & 13 & 20,32 \\
\hline \multirow[t]{2}{*}{ Total } & & 55 & $85,94 \%$ \\
\hline & 5 & 0 & 0,0 \\
\hline \multirow{2}{*}{ Perawatan Borderline } & 6 & 5 & 7,81 \\
\hline & 7 & 1 & 1,56 \\
\hline \multirow[t]{2}{*}{ Total } & & 6 & 9,37 \\
\hline & 8 & 3 & 4,69 \\
\hline \multirow[t]{2}{*}{ Sangat butuh perawatan } & 9 & 0 & 0,0 \\
\hline & 10 & 0 & 0,0 \\
\hline Total & & 3 & 4,69 \\
\hline Nilai keseluruhan & & 64 & 100 \\
\hline
\end{tabular}

Tabel 4. Distribusi Dental Health Component

\begin{tabular}{cccr}
\hline Dental heatlh component (DHC) & Nilai & $\mathrm{n}$ & $\mathbf{( \% )}$ \\
\hline Tidak/butuh perawatan ringan & 1 & 15 & 23,44 \\
Total & 2 & 18 & 28,12 \\
Perawatan Borderline & & 33 & 51,56 \\
Total & 3 & 23 & 35,94 \\
& & 23 & 35,94 \\
Sangat butuh perawatan & 4 & 5 & 7,81 \\
Total & 5 & 3 & 4,68 \\
Nilai keseluruhan & & 8 & 12,49 \\
& & 64 & 100 \\
\hline
\end{tabular}

Tabel 5. Distribusi AC berdasarkan jenis kelamin

\begin{tabular}{|c|c|c|c|c|c|}
\hline \multirow{2}{*}{ Aesthetic Component (AC) } & \multirow{2}{*}{ Nilai } & \multicolumn{2}{|c|}{ Laki-laki } & \multicolumn{2}{|c|}{ Perempuan } \\
\hline & & $\mathrm{n}$ & $\%$ & $n$ & $\%$ \\
\hline & 1 & 9 & 33,33 & 14 & 37,83 \\
\hline \multirow{3}{*}{$\begin{array}{l}\text { Tidak/butuh } \\
\text { ringan }\end{array}$} & 2 & 3 & 11,11 & 11 & 29,72 \\
\hline & 3 & 3 & 11,11 & 2 & 5,40 \\
\hline & 4 & 6 & 22,22 & 7 & 18,91 \\
\hline \multirow[t]{2}{*}{ Total } & & 21 & 77,77 & 34 & 91,86 \\
\hline & 5 & 0 & 0,0 & 0 & 0,0 \\
\hline \multirow[t]{2}{*}{ Perawatan Borderline } & 6 & 3 & 11,11 & 2 & 5,40 \\
\hline & 7 & 1 & 3,70 & 0 & 0,0 \\
\hline \multirow[t]{2}{*}{ Total } & & 4 & 14,81 & 2 & 5,40 \\
\hline & 8 & 2 & 7,40 & 1 & 2,70 \\
\hline \multirow[t]{2}{*}{ Sangat butuh perawatan } & 9 & 0 & 0,0 & 0 & 0,0 \\
\hline & 10 & 0 & 0,0 & 0 & 0,0 \\
\hline Total & & 2 & 7,40 & 1 & 2,70 \\
\hline Nilai keseluruhan & & 27 & 100 & 37 & 100 \\
\hline
\end{tabular}


Tabel 6. Distribusi DHC berdasarkan jenis kelamin

\begin{tabular}{lcrrrr}
\hline \multirow{2}{*}{$\begin{array}{c}\text { Dental Health } \\
\text { Component (DHC) }\end{array}$} & \multirow{2}{*}{ Nilai } & \multicolumn{2}{c}{ Laki-laki } & \multicolumn{2}{c}{ Perempuan } \\
\cline { 3 - 6 } & & $\mathrm{n}$ & & $\mathrm{n}$ & $\%$ \\
\hline Tidak/butuh & 1 & 8 & 29,62 & 7 & 18,91 \\
perawatan ringan & 2 & 5 & 18,51 & 13 & 35,13 \\
$\quad$ Total & & 13 & 48,13 & 20 & 54,04 \\
Perawatan borderline & 3 & 10 & 37,03 & 13 & 35,13 \\
$\quad$ Total & & 10 & 37,03 & 13 & 35,13 \\
Sangat butuh & 4 & 1 & 3,70 & 4 & 10,81 \\
perawatan & & & & & \\
& 5 & 3 & 11,11 & 0 & 0,0 \\
$\quad$ Total & & 4 & 14,81 & 4 & 10,81 \\
$\quad$ Nilai keseluruhan & & 27 & 100 & 37 & 100 \\
\hline
\end{tabular}

Tabel 7. Distribusi nilai AC dan DHC

\begin{tabular}{lcccr}
\hline \multirow{2}{*}{ Kebutuhan perawatan } & \multicolumn{2}{c}{$\begin{array}{c}\text { Aesthetic Component } \\
\text { (AC) }\end{array}$} & \multicolumn{2}{c}{$\begin{array}{c}\text { Dental Health } \\
\text { Component (DHC) }\end{array}$} \\
\cline { 2 - 5 } & $\mathrm{n}$ & $\%$ & $\mathrm{n}$ & $\%$ \\
\hline $\begin{array}{l}\text { Tidak/butuh perawatan } \\
\text { ringan }\end{array}$ & 55 & 85,94 & 33 & 51,56 \\
Perawatan borderline & 6 & & & \\
Sangat butuh perawatan & 3 & 9,37 & 23 & 35,94 \\
$\quad$ Total & 64 & 4,69 & 8 & 12,5 \\
& & 100 & 64 & 100 \\
\hline
\end{tabular}

\section{BAHASAN}

Data pada Tabel 3 menunjukkan, sebagian besar subjek penelitian terdapat pada kelompok yang tidak/butuh perawatan ringan yaitu sebanyak 85,94\%. Hasil ini tidak jauh berbeda dengan penelitian oleh Endang yang dilakukan pada siswa SMA di kecamatan Malalayang Manado tahun 2011 dengan kelompok yang tidak/butuh perawatan ringan mendapat hasil lebih banyak. ${ }^{4}$ Bagi peneliti hal ini mungkin dapat disebabkan karena kesadaran mereka untuk melakukan kunjungan ke dokter gigi dalam hal perawatan maloklusi lebih tinggi dikarenakan keadaan sosial ekonomi yang menunjang. Perlu diketahui bahwa tindakan kontrol ke dokter gigi sejak usia anak merupakan salah satu tindakan pencegahan terjadinya maloklusi. Peneliti melihat sebagian besar sampel merupakan siswa binaan khusus dengan tingkat sosial ekonomi yang menunjang. Tingkat sosial ekonomi merupakan salah satu faktor penunjang tindakan pencegahan maloklusi. Masalah maloklusi dapat timbul sejak usia anak masih sangat muda dan kelainan dapat berkembang seiring dengan bertambahnya usia anak jika tidak segera mendapatkan penanganan yang baik, maka perlu dilakukan tindakan kontrol ke dokter gigi dalam hal ini untuk mencegah kelainan tidak bertambah parah, namun berdasarkan pengalaman peneliti sebagian orang memiliki kesadaran mengenai masalah maloklusi yang dapat timbul sejak usia anak dan harus dilakukannya kunjungan ke dokterg gigi tetapi tidak dilakukan karena tingkat ekonomi yang tidak menunjang, dalam hal ini orang tidak mampu membayar biaya perawatan ortodonti dikarenakan perawatannya yang tergolong tinggi, hal ini didukung dari penelitian sebelumnya oleh Endang mendapatkan hasil hampir sama dengan alasan tingkat sosial ekonomi menjadi faktor besarnya nilai tidak/sedikit butuh perawatan. ${ }^{4}$ Penelitian oleh Mandal di Manchester mengemukakan bahwa status sosial ekonomi mempengaruhi kebutuhan perawatan ortodonti. ${ }^{5}$ Penelitian oleh Oktavian menunjukan bahwa 82,6\% subjek berdasarkan keyakinan atau kesadaran memiliki susunan gigi baik, 56,0\% subjek berdasarkan pekerjaan orang tuanya sebagai guru, perawat, bidan, apoteker, PNS, pegawai swasta memiliki susunan gigi baik dan 1,6\% subjek berdasarkan pekerjaan orang tuanya petugas jalanan, buruh, pembantu rumah 
tangga, tukang cuci, buruh tani memiliki susunan gigi buruk. ${ }^{6}$

Data pada Tabel 4 dapat dilihat berdasarkan pemeriksaan DHC menunjukan 51,56\% masuk dalam kategori tidak/butuh perawatan ringan, 35,94\% membutuhkan perawatan borderline dan delapan orang sangat butuh perawatan ortodonti. Penelitian pada anak usia remaja di Spanyol oleh Manzanera dkk tahun 2008 menyatakan bahwa orang yang tidak/butuh perawatan ringan lebih banyak, dibandingkan dengan perawatan borderline dan kategori sangat butuh perawatan. ${ }^{7}$ Hal ini dapat disebabkan karena tingkat kesadaran dalam hal perawatan pencegahan maloklusi cukup tinggi. Peneliti juga berpendapat bahwa sejak kecil mereka sudah diajarkan bagaimana cara berperilaku yang baik dan menjauhi kebiasaan-kebiasaan buruk yang bisa mempengaruhi terjadinya maloklusi, Hansu mengemukakan bahwa pengetahuan orang tua dapat mempengaruhi kebutuhan perawatan ortodonti. $^{8} \quad$ Setyowati meneliti bahwa $67,6 \%$ subjek memiliki nilai kesehatan gigi yang baik dengan pendidikan orang tuanya terakhir perguruan tinggi. $^{9} \quad$ Terdapat perbedaan pada tabel 3 dan 4, dalam hal ini presentase perawatan borderline pada DHC yang cukup tinggi dibandingkan dari segi AC. Hal ini dapat disebabkan karena cara penilaian dari AC hanya melihat sisi keenam gigi anterior berbeda dengan DHC menggunakan pemeriksaan dan pengukuran terhadap poin-poin tertentu. Kelainan yang sering ditemukan dalam penelitian oleh peneliti yaitu overjet yang menyimpang dari ukuran normalnya diukur dari ujung insisal insisivus rahang atas terhadap permukaan labial insisivus rahang bawah, terdapat juga crossbite pada gigi bagian depan maupun gigi bagian belakang serta gigi yang bergeser tidak pada tempatnya. Peneliti berpendapat kelainan-kelainan tersebut yang dapat menyebabkan keadaan gigi geligi yang terlihat buruk jika dilihat dari keadaan dalam mulut meskipun dilihat dari sisi depan mulut terlihat baik.

Pada Tabel 5 dan 6 pemeriksaan AC dan DHC berdasarkan jenis kelamin dapat dilihat bahwa, hasil pemeriksaan AC tidak jauh berbeda anatara laki-laki dan perempuan. Pada kelompok laki-laki yang tidak/butuh perawatan ringan berjumlah 22 orang dan kelompok perempuan 34 orang, yang membutuhkan perawatan borderline pada kelompok laki-laki tiga orang dan dua orang kelompok perempuan, yang sangat butuh perawatan pada laki-laki berjumlah dua orang dan pada perempuan berjumlah satu orang. Hasil yang sama pada pemeriksaan DHC yang menunjukan sedikit perbedaan antara kelompok laki-laki dan perempuan.

Dari hasil diatas dapat dilihat bahwa kelompok laki-laki lebih membutuhkan perawatan ortodonti dibandingkan kelompok perempuan. Hasil yang sama didapat dari penelitian Hedayati di Iranian tahun 2007 tentang IOTN berdasarkan jenis kelamin yang menyimpulkan bahwa 20,49\% laki-laki membutuhkan perawatan ortodonti sedangkan hanya $15,21 \%$ saja dari kelompok perempuan yang membutuhkan perawatan ortodonti. ${ }^{10}$ Peneliti berpendapat bahwa sebagian besar laki-laki tidak terlalu peduli akan masalah gigi dan mulut yang dapat menyebabkan kelainan maloklusi, mereka lebih memperioritaskan hobi mengingat banyaknya hobi yang dapat dipilih oleh laki-laki dibandingkan perempuan. Alasan lainnya perempuan lebih peka terhadap kondisi dan penampilan tubuh sampai pada penampilan gigi geliginya sehingga jika terjadi hal-hal yang dapat menyinggung terjadinya masalah maloklusi mereka akan lebih cepat merespon sehingga harus dilakukan tindakan pencegahan maloklusi salah satunya melakukan kunjungan ke dokter gigi, hal ini didukung oleh penelitian Hansu dengan jenis kelamin laki-laki lebih butuh perawatan ortodonti dikarenakan perempuan lebih memiliki keinginan untuk melakukan perawatan ortodonti. ${ }^{8}$

Data 7 hasil pemeriksaan yang dilakukan di SMA Negeri 3 Tondano menunjukan bahwa terdapat perbedaan antara nilai AC dan DHC. Dapat dilihat dari segi AC yang tidak/butuh perawatan ringan berjumlah $85,94 \%$, pada segi DHC yang tidak/butuh perawatan ringan berjumlah 33 51,56\%. Hal ini disebabkan karena pada pemeriksaan AC hanya menilai secara subjektif dengan melihat sisi penampilan gigi seseorang saja, yang diperlihatkan yaitu keenam gigi anterior, sedangkan pada pemeriksaan DHC menilai secara objektif dilakukan pemeriksaan dan pengukuran terhadap keadaan gigi dan mulut menggunakan instrument yang telah tersedia, dalam hal ini pemeriksaan dan pengukuran yang dilakukan menyangkut missing teeth, overjet, crossbite,displacement of teeth, dan overbite. Dari segi DHC pemeriksaan dilakukan dengan cara menugukur jarak 
keadaan gigi geligi yang terlihat menyimpang pada gigi geligi bagian depan dan belakang, peneliti sering menemukan kelaian seperti crossbite yang terjadi pada gigi geligi bagian depan dan belakang, terjadi pergeseran gigi pada tempat yang tidak seharusnya, dan pelebaran jarak diluar jarak normal pada overjet dan overbite. Dapat disimpulkan bahwa pada penilaian AC keadaan gigi geliginya dapat dikatakan baik, namun dari segi DHC keadaan gigi geliginya tidak dapat dikatakan baik.

Hasil penelitian sesuai dengan penelitian yang dilakukan oleh Mandall menggunakan nilai AC dan DHC pada usia remaja di Manchester tahun 2006 dengan hasil, dari segi AC dan DHC yang tidak/butuh perawatan ringan lebih banyak dibandingkan perawatan borderline dan sangat butuh perawatan. ${ }^{11}$

\section{SIMPULAN}

Berdasarkan pemeriksaan Aesthetic Component (AC) sebagian besar subjek 85,94\% tidak/butuh perawatan ortodonti. Berdasarkan pemeriksaan Dental Health Component (DHC) lebih dari setengah subjek $51,56 \%$ yang tidak/butuh perawatan ortodonti.

\section{DAFTAR PUSTAKA}

1. Achmad H. Penanganan delayed eruption karena impaksi gigi insisifus sentralis kiri dengan surgical exposure pada anak. Dentofasial 2009 Apr ; 8(1) : 4854

2. Yovela Y. Penatalaksanaan Kasus Protusif Gigi Anterior Atas Dengan Kelainan Periodontal Pada Pasien Dewasa: fakultas kedoktera gigi universitas Indonesia: Tahun 2009.

3. Deddy D. The use of index of orthodontic treatment need (IOTN) as an evaluation of treatment with removable appliance. 2011. Available from: URL : http://dentj.fkg.unair.ac.id/detail_abstra ct359.html

4. Endang S. Kebutuhan Perawatan Ortodonsi
Berdasarkan Index of Orthodontic Treatment Need (IOTN) Pada Siswa Di Kecamatan Malalayang Manado: (skripsi) Tahun 2010.

5. Mandall NA, Mc Cord JF, Blinkhom AS, Washington $\mathrm{HV}$ and Obrien $\mathrm{KD}$. Perceived aesthetic impact of malocclution and oral self perception in 14-15 years old Asian and Caucasian children in greater Manchester. Eur J Orthodont. 2006;21.p. 175-83

6. Dewi O. Analisis hubungan maloklusi dengan kualitas hidup remaja SMU Kota Medan 2007. Fakultas Kedokteran Gigi Universitas Sumatera Utara; 2010. h. 10-27. Available from : URL

repository.usu.ac.id/bitsteam/12345678 9/669/1/08e00229.pdf

7. Manzanera D, Company JM, Silla JM, Gandia JL. Orthodontic Treatment Need In Spanish Scoolchildren: an epidemiological study using the Index Of Orthodontic Treatment Need. 2008. Available from : URL : http://www.ejo.oxfordjournals.org

8. Hansu C. Kebutuhan Perawatan Ortodonsi Berdasarkan Index Of Othodontic Treatment Need di SMP Theodorus Kotamobagu. Tahun 2013 (Skripsi)

9. Setyowati RE. Hubungan Status Sosial Ekonomi Dengan Status Kehilangan Gigi Pada Remaja. Tahun 2013

10. Burden D, Pine C. Index of orthodontic treatment need modified for use in epidemiological surveys: modified IOTN [online]. [cited 2010 juni 02]; Available from: URL : http://www.ncbi.nlm.nih.gov/pubmed/1 1409681

11. Albarakati SF. Self perception of malocclusion of Saudi patients using the Aesthetic Component of IOTN. 2006; Pakistan oral \& dental journal vol 27. 